\section{MULTI-CRITERIA GROUP DECISION MAKING IN THE SUPPLIER SELECTION OF CAPITAL PARTS}

\author{
MARCIO RODRIGUES, EVA SIROVA \\ Technical University of Liberec, Business Administration \\ Department, Liberec, Czech Republic
}

DOI : 10.17973/MMSJ.2019 122019157

e-mail : eva.sirova@tul.cz

Reaching a consensus in strategic and key decision processes always have been a big challenge in top management in enterprises globally, as they are required to make decisions much more accurate and quicker due to the increasing amount of inputs in the current reality of Industry 4.0. This article presents a case study of a multi-criteria group decision making (MCGDM) model for the supplier selection of a capital spare part in a small industry using the Analytic Hierarchy Process (AHP). The results obtained through this model are compared and discussed among all decision makers.

KEYWORDS

AHP, group decision making process, maintenance, reliability, spare parts

\section{INTRODUCTION}

Following previous research of the authors, the aim of this article is to create a model of the decision-making process of buying spare parts (SP) from different suppliers. This article presents a case study of a multi-criteria group decision making (MCGDM) model for the supplier selection of a capital spare part in a small industry using the Analytic Hierarchy Process (AHP). For the decision between 3 suppliers for the purchase process of a capital spare part (SP) were asked three decision makers inherent in the process. For this model, 6 attributes (supplier lead times, availability, spare part unitary purchase price, part quality, aftersales customer service and sustainability) were grouped into 2 hybrid criteria (LogisticsEconomic and Quality-Sustainability).

The contribution can be summarized as follows: The article presents an overview of research on decision support models and spare parts parts logistices in the business environment based on the results of the literature review. The second section describes the methodological steps followed within the creation of the model for the group decision-making process of the supplier choice. Section 3 presents the results of the case study. It includes a brief company description, explanation of the chosen criteria and presents the hierarchy diagram of the AHP. The final section of the paper summarizes the results of the research and their possible limitations.

\section{LITERATURE REVIEW}

The position and role of maintenance and spare parts in risk management is crucial. It is about defining the risk in relation to critical failure and determining the impact of preventive maintenance and backup on the level of risk of running of the key spare parts.

Preventive maintenance increases safety and risk [Huai-Wei 2019]. Spare parts management is a part of maintenance that meets the requirements for maintaining the assets in a serviceable condition; preventing disfunctions, ensuring operational safety and spending optimal maintenance costs for the spare parts.

Spare parts management means coordination of activities related to purchasing and control of spare parts with respect to risk [IEC 60050-191:1990]. According to standard ISO/IEC 51 risk management is defined as the systematic use of management policies, procedures and working techniques for tasks related to contextualization, discovery, analysis, evaluation, treatment, monitoring and risk communication.

The increasing cost, complexity of maintenance, other uncertainties, and their effect on production has initiated a need for adequate and proper planning, management, and omission of the maintenance process [Toms 2008].

Structured and scientific decision-making process is essential to making rational and applicable decisions, especially in the dynamic business environment, where dealing with complexity and uncertainty is the key factor for success for the companies [Koksalmis 2019].

The complexity of the socio-economic environment increases, it becomes harder for a single decision maker to deal with all the relevant features of a problem [Dey 2017]. Many decisionmaking problems in the real world have to take place in a group environment [Liao 2017]. Moving from a single decision maker to multiple decision makers adds too much complexity to the analysis. For this reason, in recent years, researchers have become more interested in approaches related to group decision making (GDM) problems [Qang 2015].

Decision makers' opinions are expressed through a process of group decision making and aggregated to obtain the performance rating with respect to all of the attributes for each maintenance procedure alternative [Asuquo 2019].

\section{METHODS AND OBJECTIVES}

The research methodology used to conduct this case study consists of the following steps:

- a brief literature review of maintenance and recent applications of MCGDM methods;

- identification of the motivation for this work and decision of using AHP;

- selection of the company and its current key decision process; the conception of the model, criteria and attributes;

- interviews with involved decision makers; processing of the collected data and discussion of the results outputted from the model.

\section{CASE STUDY}

The company where the present study was conducted is an industrial business, which mainly manufactures components to the automotive industry. The lead department is maintenance, which also controls their stock levels and their complete inventory management. The spare parts have their own warehouse, and the levels of the safety stocks are set according to previous yearly demands. Many of the spare parts are critical to the production process, which are considered capital spare parts, mostly due to their high purchasing costs and supplier lead times. 


\subsection{Copper rods as a capital part}

The involved leadership have decided to improve the purchase process with the use of the proposed MCDM approach with its most critical capital part: the copper rods. For this material, there are currently three suppliers from two different countries: one from Germany (hereafter mentioned as Supplier $1)$, and two from the Czech Republic, where one is from the Central Bohemian Region (Supplier 2) and the other from the North Bohemian Region (Supplier 3). Among all of them, Supplier 1 delivers the best quality of the parts but holds the highest price and it is the most distant from the company factory.

\subsection{The decision makers}

In this article and also agreed within the company that to the reliability of the proposed approach, the decision makers for this decision process were the maintenance, production and quality managers, respectively, as their departments have boundaries in the selected problematic. The maintenance manager, a senior electrical engineer, is the focal person for the copper rods purchasing process, has stayed four years in his position and has a solid technical background. The production manager, a senior mechanical engineer, has been five years in the current position. The reasons for judgments were affected by the main task of the production management: produce and deliver the goods to the customer. The delivery costs for the parts are less significant than the production downtimes caused by the eventual lack of parts. The quality manager, a senior mechanical engineer, has been ten years in his position, previously working as a lead quality inspector. The main reasons for his judgments were affected by the zero-defect policy for quality control of spare parts, where the part quality is the most critical aspect to evaluate a supplier, much higher than both price and delivery lead time.

\subsection{The AHP hierarchy model}

What could be gathered from the conducted interviews with the managers as mentioned earlier, these relevant factors that would influence the SP purchasing process were presented based on previous consolidated literature, and decided to choose six as attributes:

- Delivery cycle time: time interval between the date where the company's issues a purchase order and date of arrival at their warehouse;

- Supplier availability: response rate from the supplier for emergency or unplanned delivery;

- $\quad$ Price: the unitary purchase price of the goods;

- Part quality: percentage of accepted parts per batch after quality inspection at the company;

- Aftersales customer service: response rate of the supplier;

- Sustainability: remanufacture percentage rate of scrapped parts at the supplier.

The authors grouped them into two hybrid criteria, mainly considering the feedback given by the managers regarding the relationship between the attributes: Logistic-Economic and Quality-Sustainability, as presented below in Figure 1 and Table 1.

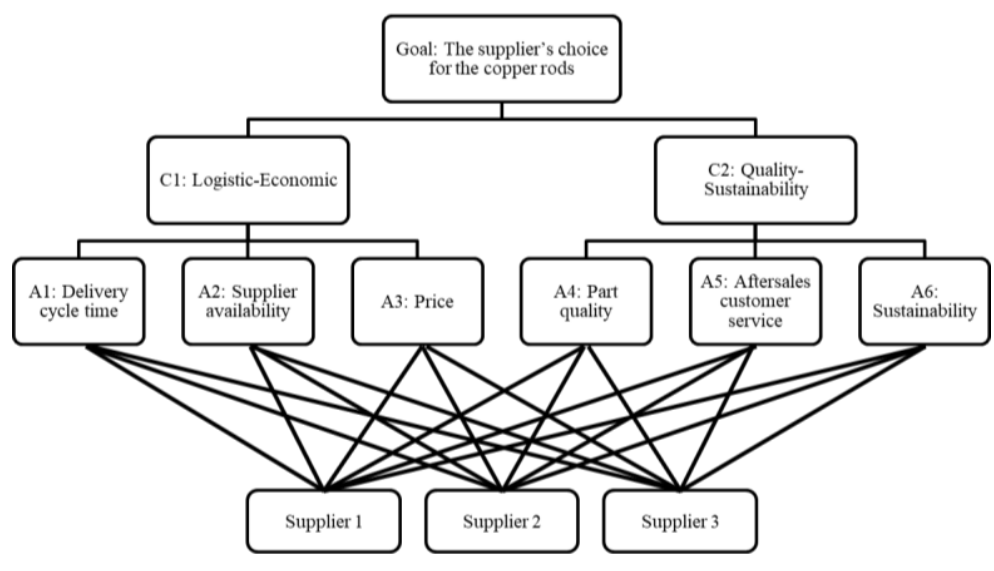

Figure 1. Hierarchical tree of the copper rods supplier's choice decision process

For this pairwise comparison between attributes and alternatives, the three managers made their judgments based on Saaty's fundamental scale, only considering the odd values. In order to reflect the judgments of all decision-makers in the overall ranking, the geometric mean between their scores was used to consolidate them into a combined assessment, which will be discussed in the next section of this article.

\begin{tabular}{|c|c|c|c|}
\cline { 2 - 4 } \multicolumn{1}{c|}{ Logistic-Economic } & Delivery Cycle Time & Price & Supplier Availability \\
\hline Delivery Cycle Time & 1 & 5 & 4 \\
\hline Price & $1 / 5$ & 1 & $1 / 3$ \\
\hline Supplier Availability & $1 / 4$ & 3 & 1 \\
\hline Inconsistency & $8.25 \%$ & \multicolumn{2}{c}{}
\end{tabular}

Table 1. Pairwise comparison between attributes and alternatives

\section{RESULTS AND DISCUSSION}

In order to structure the inputs from the managers, especially their judgments, an input formulary was created, and then all weights and grades were inputted into the software Super Decisions, by the Creative Decisions Foundation. The inconsistency check of the judgments, one essential step to ensure the reliability of the outputs when using AHP.

\subsection{Decision Makers Inputs}

As previously mentioned before, each manager has a different perception of the process, which leads to a different evaluation reflected in the scores. Table 2 shows the evaluations of each manager concerning the alternatives and criteria.

Furthermore, as a premise to accurately use the AHP method, Saaty's fundamental scale for scoring was used to reflect the numerical judgment of the decision-makers, as presented in Figure 2 below.

As an example, the first numerical row of table 2 means that Supplier 2 has a very strong relative importance when compared to Supplier 1 with regard to the Attribute Delivery Cycle Time according to the Maintenance Manager.

According to the Production Manager, on the other hand, Supplier 2 has strong relative importance compared to Supplier 1 concerning the same Attribute and agrees with the Quality Manager, who had the same evaluation. The same numerical scale was used in tables 3 and 4 . 


\begin{tabular}{|c|c|c|c|c|c|c|c|c|c|}
\hline \multirow[b]{3}{*}{$\begin{array}{l}\text { Attributes } \\
\text { (Subcriteria) }\end{array}$} & \multicolumn{9}{|c|}{ Decision Makers } \\
\hline & \multicolumn{3}{|c|}{$\begin{array}{c}\text { Maintenance } \\
\text { manager }\end{array}$} & \multicolumn{3}{|c|}{$\begin{array}{c}\text { Production } \\
\text { manager }\end{array}$} & \multicolumn{3}{|c|}{ Quality manager } \\
\hline & 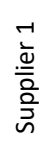 & 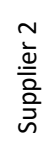 & 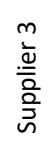 & $\frac{\stackrel{-1}{0}}{\frac{.0}{0}}$ & 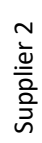 & 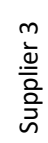 & 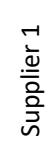 & 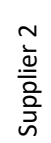 & 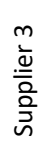 \\
\hline \multirow{3}{*}{$\begin{array}{c}\text { Delivery } \\
\text { Cycle Time }\end{array}$} & $\begin{array}{l}1 / \\
7\end{array}$ & 7 & & $\begin{array}{c}1 / \\
5\end{array}$ & 5 & & $\begin{array}{c}1 / \\
5\end{array}$ & 5 & \\
\hline & $\begin{array}{c}1 / \\
9\end{array}$ & & 9 & $\begin{array}{c}1 / \\
9\end{array}$ & & 9 & $\begin{array}{l}1 / \\
7\end{array}$ & & 7 \\
\hline & & 5 & $\begin{array}{c}1 / \\
5\end{array}$ & & 5 & $\begin{array}{l}1 / \\
5\end{array}$ & & 3 & $\begin{array}{l}1 / \\
3\end{array}$ \\
\hline \multirow{3}{*}{$\begin{array}{c}\text { Part } \\
\text { Quality }\end{array}$} & 7 & $\begin{array}{l}1 / \\
7\end{array}$ & & 7 & $\begin{array}{l}1 / \\
7\end{array}$ & & 7 & $\begin{array}{l}1 / \\
7\end{array}$ & \\
\hline & $\begin{array}{l}1 / \\
9\end{array}$ & & 9 & 9 & & $\begin{array}{c}1 / \\
9\end{array}$ & 9 & & $\begin{array}{c}1 / \\
9\end{array}$ \\
\hline & & 3 & $\begin{array}{c}1 / \\
3\end{array}$ & & 5 & $\begin{array}{c}1 / \\
5\end{array}$ & & 3 & $\begin{array}{c}1 / \\
3\end{array}$ \\
\hline \multirow{3}{*}{$\begin{array}{c}\text { Supplier } \\
\text { Availability }\end{array}$} & $\begin{array}{c}1 / \\
7\end{array}$ & 7 & & $\begin{array}{c}1 / \\
5\end{array}$ & 5 & & $\begin{array}{l}1 / \\
7\end{array}$ & 7 & \\
\hline & $\begin{array}{l}1 / \\
9\end{array}$ & & 9 & $\begin{array}{l}1 / \\
7\end{array}$ & & 7 & $\begin{array}{c}1 / \\
9\end{array}$ & & 9 \\
\hline & & 5 & $\begin{array}{c}1 / \\
5\end{array}$ & & $\begin{array}{l}1 / \\
3\end{array}$ & 3 & & $\begin{array}{c}1 / \\
5\end{array}$ & 5 \\
\hline \multirow{3}{*}{$\begin{array}{c}\text { Aftersales } \\
\text { Customer } \\
\text { Service }\end{array}$} & 5 & $\begin{array}{c}1 / \\
5\end{array}$ & & 5 & $\begin{array}{l}1 / \\
5\end{array}$ & & 7 & $\begin{array}{l}1 / \\
7\end{array}$ & \\
\hline & 7 & & $\begin{array}{l}1 / \\
7\end{array}$ & 7 & & $\begin{array}{l}1 / \\
7\end{array}$ & 9 & & $\begin{array}{l}1 / \\
9\end{array}$ \\
\hline & & 3 & $\begin{array}{c}1 / \\
3\end{array}$ & & 5 & $\begin{array}{l}1 / \\
5\end{array}$ & & 7 & $\begin{array}{l}1 / \\
7\end{array}$ \\
\hline \multirow{3}{*}{ Price } & $\begin{array}{l}1 / \\
7\end{array}$ & 7 & & $\begin{array}{c}1 / \\
5\end{array}$ & 5 & & $\begin{array}{l}1 / \\
5\end{array}$ & 5 & \\
\hline & $\begin{array}{c}1 / \\
9\end{array}$ & & 9 & $\begin{array}{l}1 / \\
7\end{array}$ & & 7 & $\begin{array}{l}1 / \\
7\end{array}$ & & 7 \\
\hline & & 5 & $\begin{array}{c}1 / \\
5\end{array}$ & & $\begin{array}{l}1 / \\
3\end{array}$ & 3 & & $\begin{array}{l}1 / \\
3\end{array}$ & 3 \\
\hline \multirow{3}{*}{$\begin{array}{c}\text { Sustainabil } \\
\text { ity }\end{array}$} & 3 & $\begin{array}{l}1 / \\
3\end{array}$ & & 3 & $\begin{array}{l}1 / \\
3\end{array}$ & & 3 & $\begin{array}{c}1 / \\
3\end{array}$ & \\
\hline & 5 & & $\begin{array}{l}1 / \\
5\end{array}$ & 5 & & $\begin{array}{l}1 / \\
5\end{array}$ & 5 & & $\begin{array}{l}1 / \\
5\end{array}$ \\
\hline & & 3 & $\begin{array}{c}1 / \\
3\end{array}$ & & 3 & $\begin{array}{l}1 / \\
3\end{array}$ & & 3 & $\begin{array}{c}1 / \\
3\end{array}$ \\
\hline
\end{tabular}

Table 2. Evaluations of the suppliers by each decision maker
Numerical scale

Verbal scale

$\begin{array}{cl}1 & \text { Equal importance } \\ 3 & \text { Moderate importance } \\ 5 & \text { Strong importance } \\ 7 & \text { Very strong importance } \\ 9 & \text { Extreme importance } \\ 2,4,6,8 & \text { Intermediate values }\end{array}$

Flgure 2. Saaty's fundamental scale for judgment of decision makers

\subsection{AHP Combined Model Inputs}

Considering the judgments of the three managers involved in the purchasing process, and using the geometric mean, the next tables extracted from the software Super Decisions shows the group evaluation between the attributes, as the relative importance between the criteria is 1 .

In table 3, the judgments for the relative importance between attributes of each criteria are presented. Table 4 presents the evaluation of the pairwise comparison between the three alternatives according to their performance in each attribute. In the next subsection, the main output obtained from these inputs using AHP is shown.

\begin{tabular}{|c|c|c|c|}
\cline { 2 - 4 } \multicolumn{1}{c|}{$\begin{array}{c}\text { Quality- } \\
\text { Sustainability }\end{array}$} & $\begin{array}{c}\text { Aftersales } \\
\text { Customer Service }\end{array}$ & $\begin{array}{c}\text { Part } \\
\text { Quality }\end{array}$ & Sustainability \\
\hline $\begin{array}{c}\text { Aftersales } \\
\text { Customer Service }\end{array}$ & 1 & $1 / 3$ & 2 \\
\hline Part Quality & 3 & 1 & 3 \\
\hline Sustainability & $1 / 2$ & $1 / 3$ & 1 \\
\hline Inconsistency & $5.16 \%$ &
\end{tabular}

Table 3. Comparison and judgment for the hybrid criteria LogisticEconomic 


\begin{tabular}{|c|c|c|c|c|c|c|c|}
\hline \multicolumn{4}{|c|}{ Criteria 1: Logistic-Economic } & \multicolumn{4}{|c|}{ Criteria 2: Quality-Sustainability } \\
\hline 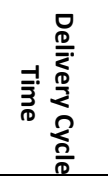 & $\begin{array}{l}\frac{n}{\frac{0}{0}} \\
\frac{\overline{0}}{\bar{D}} \\
\frac{1}{\square}\end{array}$ & $\begin{array}{l}n \\
\frac{n}{\overline{0}} \\
\frac{\overline{\bar{D}}}{N} \\
\stackrel{n}{n}\end{array}$ & $\begin{array}{l}\frac{n}{\frac{\eta}{\bar{c}}} \\
\frac{\overline{0}}{\overline{\bar{D}}} \\
\bar{\omega}\end{array}$ & 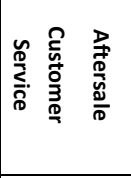 & 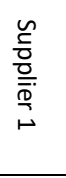 & $\begin{array}{l}\frac{n}{\frac{n}{0}} \\
\frac{\overline{0}}{\overline{\bar{D}}} \\
\frac{N}{N}\end{array}$ & $\begin{array}{l}\frac{n}{\frac{E}{0}} \\
\frac{\overline{0}}{\overline{\bar{D}}} \\
\omega\end{array}$ \\
\hline $\begin{array}{c}\text { Supplier } \\
1\end{array}$ & 1 & $1 / 5$ & $1 / 3$ & $\begin{array}{c}\text { Supplier } \\
1\end{array}$ & 1 & 3 & 3 \\
\hline $\begin{array}{c}\text { Supplier } \\
2\end{array}$ & 5 & 1 & 3 & $\begin{array}{c}\text { Supplier } \\
2\end{array}$ & $1 / 3$ & 1 & 2 \\
\hline $\begin{array}{c}\text { Supplier } \\
3\end{array}$ & 3 & $1 / 3$ & 1 & \begin{tabular}{|c|} 
Supplier \\
3
\end{tabular} & $1 / 3$ & $1 / 2$ & 1 \\
\hline \multicolumn{4}{|c|}{ Inconsistency } & \multicolumn{4}{|c|}{ Inconsistency } \\
\hline ㄱ. & $\begin{array}{l}\frac{n}{\frac{0}{0}} \\
\frac{\overline{0}}{\bar{D}} \\
\frac{1}{1}\end{array}$ & $\begin{array}{l}\frac{n}{\frac{5}{0}} \\
\frac{0}{\bar{D}} \\
\frac{N}{n}\end{array}$ & $\begin{array}{l}\frac{\tilde{c}}{\frac{0}{0}} \\
\frac{\overline{\bar{D}}}{\bar{D}} \\
\bar{\omega}\end{array}$ & 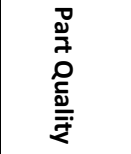 & $\begin{array}{l}\frac{n}{\frac{5}{0}} \\
\frac{0}{\overline{0}} \\
\frac{\bar{\sigma}}{5}\end{array}$ & $\begin{array}{l}\frac{n}{\frac{5}{0}} \\
\frac{0}{\bar{D}} \\
\frac{N}{N}\end{array}$ & $\begin{array}{l}\frac{n}{\frac{5}{0}} \\
\frac{\overline{0}}{\overline{0}} \\
\frac{0}{\omega}\end{array}$ \\
\hline $\begin{array}{c}\text { Supplier } \\
1\end{array}$ & 1 & $1 / 6$ & $1 / 8$ & $\begin{array}{c}\text { Supplier } \\
1\end{array}$ & 1 & 3 & 7 \\
\hline $\begin{array}{c}\text { Supplier } \\
2\end{array}$ & 6 & 1 & 1 & $\begin{array}{c}\text { Supplier } \\
2\end{array}$ & $1 / 3$ & 1 & 5 \\
\hline $\begin{array}{c}\text { Supplier } \\
3\end{array}$ & 8 & 1 & 1 & $\begin{array}{c}\text { Supplier } \\
3\end{array}$ & $1 / 7$ & $1 / 5$ & 1 \\
\hline \multicolumn{2}{|c|}{ Inconsistency } & \multicolumn{2}{|c|}{$0.89 \%$} & \multicolumn{4}{|c|}{ Inconsistency $\quad 6.24 \%$} \\
\hline 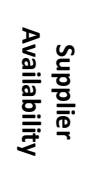 & $\begin{array}{l}\frac{n}{\frac{E}{0}} \\
\frac{\overline{0}}{\overline{\bar{D}}} \\
\stackrel{5}{5}\end{array}$ & $\begin{array}{l}\frac{n}{\frac{E}{0}} \\
\frac{\overline{0}}{\bar{N}} \\
\frac{N}{N}\end{array}$ & $\begin{array}{l}\frac{\tilde{c}}{\frac{0}{D}} \\
\frac{\overline{\bar{D}}}{\omega} \\
\frac{\omega}{\omega}\end{array}$ & 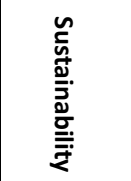 & $\begin{array}{l}\frac{n}{\frac{n}{0}} \\
\frac{\overline{0}}{\bar{D}} \\
\frac{1}{\square}\end{array}$ & $\begin{array}{l}\frac{n}{\frac{n}{0}} \\
\frac{\overline{0}}{\overline{\bar{D}}} \\
\frac{N}{N}\end{array}$ & $\begin{array}{l}\frac{n}{\frac{E}{0}} \\
\frac{\overline{0}}{\bar{\sigma}} \\
\frac{\omega}{\omega}\end{array}$ \\
\hline $\begin{array}{l}\text { Supplie } \\
\text { r } 1\end{array}$ & 1 & $1 / 3$ & $1 / 3$ & $\begin{array}{c}\text { Supplier } \\
1\end{array}$ & 1 & 3 & 5 \\
\hline $\begin{array}{c}\text { Supplie } \\
\text { r } 2\end{array}$ & 3 & 1 & 1 & $\begin{array}{c}\text { Supplier } \\
2\end{array}$ & $1 / 3$ & 1 & 3 \\
\hline $\begin{array}{l}\text { Supplie } \\
\text { r } 3\end{array}$ & 3 & 1 & 1 & $\begin{array}{c}\text { Supplier } \\
3\end{array}$ & $1 / 5$ & $1 / 3$ & 1 \\
\hline \multicolumn{2}{|c|}{ Inconsistency } & & $0 \%$ & \multicolumn{2}{|c|}{ Inconsistency } & \multicolumn{2}{|c|}{$3.70 \%$} \\
\hline
\end{tabular}

Table 4. Pairwise comparison judgment of suppliers according to each attribute

\subsection{AHP Model Outputs}

In order to consolidate the decision-maker numerical inputs, the theory behind the calculations was the Analytic Hierarchy Process (AHP) [Saaty 1977], widely consolidated in the literature.

This method consists of structured steps, including normalization of alternative judgment, criteria and attribute weights, consistency check of evaluations and consolidation of each decision-maker inputs into one MCGDM consolidated input matrix with the use of the geometric mean between of the judgment among all managers.

After computation of the group-consolidated evaluations of both criteria and attributes, the overall prioritization result between the three suppliers is presented in table 5 , denoting that the Supplier 2 is the recommended choice to provide the copper rods to the company. This result had a significant influence of some of the criteria: Delivery cycle time, Supplier
Availability and Price, calculated in the Super Decisions software.

\begin{tabular}{|c|c|c|}
\hline Name & Normalized Weights & Rank \\
\hline Supplier 1 & 0.371467 & 2 \\
\hline Supplier 2 & 0.419439 & 1 \\
\hline Supplier 3 & 0.209094 & 3 \\
\hline
\end{tabular}

Table 5. Overall ranking among alternatives using the AHP by the authors

\subsection{Comparative outputs between individual decision makers and whole model}

One main contribution of this article is to compare the outputs between the individual assessments and the whole model and how they affect the decision process. Table 6 presents the final results of the AHP model comparing the supplier choice of each decision maker and the output from the group decision making. Considering the evaluation of the maintenance manager, Supplier 1 (S1) holds the best performance. For the Production Manager, Supplier 2 (S2) would be the chosen to supply the copper rods and for the Quality Manager, also Supplier 1 is the best among all alternatives. And surprisingly, for the Group Decision Making hereafter addressed as the Whole AHP Model, which combines all evaluations among the three decision makers, Supplier 2 is the best option to buy it. The compared results are also shown in Figure 2.

\begin{tabular}{|c|c|c|c|c|c|c|c|c|}
\hline 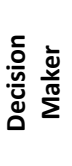 & 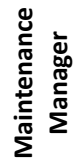 & 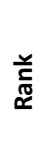 & 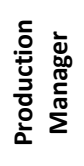 & 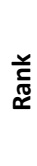 & 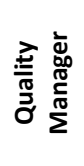 & $\begin{array}{l}\text { 兰 } \\
\text { 苋 }\end{array}$ & $\begin{array}{l}\overline{\bar{\sigma}} \\
\frac{0}{0} \\
\text { ठ }\end{array}$ & 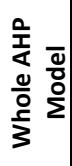 \\
\hline S 1 & $\begin{array}{c}0.487 \\
64\end{array}$ & 1 & $\begin{array}{c}0.225 \\
43\end{array}$ & 2 & $\begin{array}{c}0.544 \\
67\end{array}$ & 1 & $\begin{array}{c}0.3714 \\
67\end{array}$ & 2 \\
\hline S2 2 & $\begin{array}{c}0.233 \\
22\end{array}$ & 3 & $\begin{array}{c}0.684 \\
46\end{array}$ & 1 & $\begin{array}{c}0.310 \\
88\end{array}$ & 2 & $\begin{array}{c}0.4194 \\
39\end{array}$ & 1 \\
\hline S 3 & $\begin{array}{c}0.279 \\
14\end{array}$ & 2 & $\begin{array}{c}0.090 \\
11\end{array}$ & 3 & $\begin{array}{c}0.144 \\
45\end{array}$ & 3 & $\begin{array}{c}0.2090 \\
94\end{array}$ & 3 \\
\hline
\end{tabular}

Table 6. Comparative analysis of the overall rankings between outputs of individual decision makers and the final group decision making

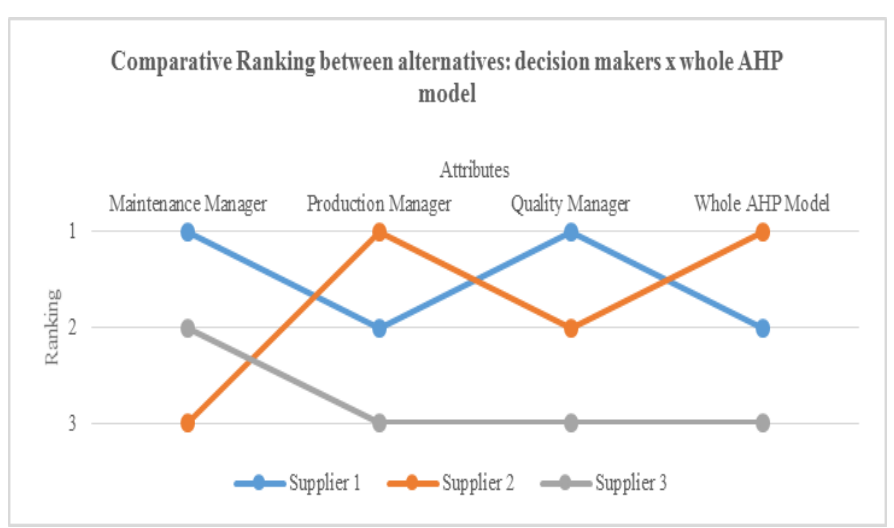

Figure 2. Comparative ranking between suppliers 


\section{CONCLUSION}

This article presented an evaluation of Group Decision making with the aid of the AHP method in the supplier's choice of a capital spare part. The first section brought an overview of the current applications of this method and a brief literature review. The case study presented the decision makers, their brief professional profiles and all model details and parameters, based on their individual assessments about the purchasing process of the copper rods. It is important to highlight with the output of this article that this methodology brings an mathematical solution to a very common problem faced in many companies involved in group decision making: reaching a consensus. Future research from this work is possible, as other aspects of MCGDM could be discussed and evaluated, bringing other perspectives of this decision process, suitable to many business segments globally.

\section{ACKNOWLEDGMENTS}

This article was supported by SGS 21301 “Project Management and Information Systems in Quality and Supply Chain Management" provided by Technical University of Liberec, Czech Republic.

\section{REFERENCES}

[Asuquo 2019] Asuquo, M. P. Application of a multiple attribute group decision making (MAGDM) model for selecting appropriate maintenance strategy for marine and offshore machinery operations, Ocean Engineering, 2019, Vol. 179, pp. 246-260, ISSN 0029-8018.

\section{CONTACTS:}

Ing. Eva Sirova, Ph.D.

Technical University of Liberec

Business Administration Department

Studentská 2, Liberec, 461 17, Czech Republic

+420 485352 353, eva.sirova@tul.cz, www.ef.tul.cz

Ing. Marcio Rodrigues

Technical University of Liberec

Business Administration Department

Studentska 2, Liberec, 461 17, Czech Republic

+420 485352 353, marcio.rodrigues@tul.cz, www.ef.tul.cz
[Dey 2017] Dey B. Group heterogeneity in multi member decision making model with an application to warehouse location selection in a supply chain. Comput. Ind. Eng., 2017, Vol. 105, pp. 101-122.

[Huai-Wei 2019] Huai-Wei L. A novel failure mode and effect analysis model for machine tool risk analysis. Reliability Engineering \& System Safety,2019, Vol. 183, 2019, pp. 173-183, ISSN 0951-8320.

[IEC 60050-191:1990] IEC 60050-191:1990 International Electrotechnical Vocabulary (IEV) - Part 191: Dependability and quality of service

[ISO/IEC 51:2014] ISO/IEC Guide 51:2014 Safety aspects -Guidelines for their inclusion in standards

[Koksalmis 2019] Koksalmis, E. Deriving decision makers' weights in group decision making: An overview of objective methods. Information Fusion, 2019, Vol. 49, pp. 146-160, ISSN 1566-2535,

[Liao 2017] Liao, A. A comparison of distinct consensus measures for group decision making with intuitionistic fuzzy preference relations. Int. J. Comput. Intell. Syst., 2017, Vol. 10, pp. 456-469, ISSN 1875-6883.

[Toms 2008] Toms, L.A., Toms, A.M., Machinery Oil Analysis Methods, Automation \& Benefits. A Guide for Maintenance Managers, Supervisors \& Technician, $3^{\text {rd }}$ edit., 2008.

[Qang 2015] Yang, Q. A straightforward approach for determining the weights of decision makers based on angle cosine and projection method. Int. J. Soc. Behav. Educ. Econ. Bus. Ind. Eng.,2015, Vol. 9, pp. 3127-3133.

[Saaty 1977] Saaty, T. L. A scaling method for priorities in hierarchical structures. Journal of mathematical psychology, Vol. 15, pp. 234-281, ISSN 0022-2496. 